Professor Dr. Robert Uerpmann-Wittzack, maître en droit

University of Regensburg

robert.uerpmann-wittzack@ur.de

http://www.ur.de/law/public-law/uerpmann-wittzack/

\title{
Serious Human Rights Violations as Potential Exceptions to Immunity: Conceptual Challenges*
}

1. Introduction 1

2. Three Different Approaches 2

2.1 The Civilist Approach: Construing Legal Rules ...................................................... 2

2.2 The Constitutional Approach: Sovereignty vs. Human Rights ..................................... 3

2.3 The State-Centred Approach: State Practice and Opinio Iuris ........................................ 5

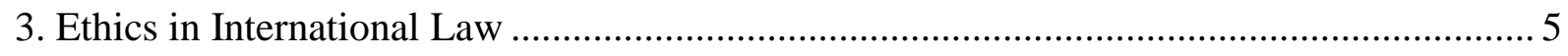

3.1 Ethics of Principled Conviction vs. Ethics of Responsibility ....................................... 5

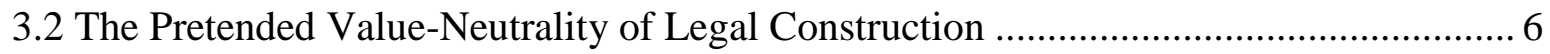

3.3 Making Values Explicit: The Constitutional Approach ............................................ 7

3.4 The Realism of a State-Centred Approach ............................................................. 7

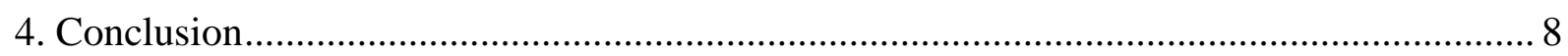

\section{Introduction}

Possible exceptions to state immunity in cases of serious violations of human rights have been discussed for twenty years now. ${ }^{1}$ In 2004, the French and the German Societies of International Law met in Berlin in order to discuss ius cogens and obligations erga omnes. ${ }^{2}$ Isabelle Pingel and Thomas Giegerich presented excellent papers on possible exceptions to

\footnotetext{
* This paper will be published in: Anne Peters, Evelyne Lagrange and Stefan Oeter, eds., Immunities in the Age of Global Constitutionalism (Leiden: Brill, 2013/2014).

${ }^{1}$ See e.g. Andrea Bianchi, “Denying State Immunity to Violators of Human Rights," Austrian Journal of Public and International Law 46 (1994): 195-229.

${ }^{2}$ Published in Christian Tomuschat and Jean-Marc Thouvenin, eds., The Fundamental Rules of the International Legal Order (Leiden: Brill, 2006).
} 
Uerpmann-Wittzack, "Serious Human Rights Violations as Potential Exceptions to Immunity: Conceptual Challenges" (2013)

state immunity in case of ius cogens violations. ${ }^{3}$ Meanwhile, the International Court of Justice in Jurisdictional Immunities ${ }^{4}$ has confirmed the analysis given by Thomas Giegerich in 2004. In this volume, Michael Bothe and Christian Tomuschat comment on the Jurisdictional Immunities Case. ${ }^{5}$ Whilst Christian Tomuschat is in line with the ICJ, Michael Bothe argues in favour of another solution as Isabelle Pingel did in 2004. This shall not be repeated here.

Rather, the present chapter shall consider the debate from a meta-level. The question is not who is right, but why scholars and courts reach divergent results. Therefore, section 2 will distinguish three different approaches to the problem. Section 3 will then directly address the ethical foundation of international law.

\section{Three Different Approaches}

\subsection{The Civilist Approach: Construing Legal Rules}

A series of scholars try to determine the limits of sovereign immunity by way of legal construction. They rely on accepted rules of international law which they apply to cases where a state has committed serious breaches of international human rights norms. This may be called a civilist approach. Some authors, for instance, contend that a state who violates fundamental human rights norms implicitly waives its immunity. ${ }^{6}$ Others apply the concept of

\footnotetext{
${ }^{3}$ Isabelle Pingel, "L’immunité des États," in Tomuschat and Thouvenin, Fundamental Rules (n. 2), 239-48; Thomas Giegerich, "Do Damages Claims Arising from Jus Cogens Violations Override State Immunity from the Jurisdiction of Foreign Courts?," in Tomuschat and Thouvenin, Fundamental Rules (n. 2), 203-38.

${ }^{4}$ ICJ, Jurisdictional Immunities of the State (Germany v. Italy: Greece Intervening), Judgment of 3 February 2012, ICJ Reports 2012, paras. 52 et seq.

${ }^{5}$ Michael Bothe, "Remedies of Victims of War Crimes and Crimes against Humanities: Some Critical Remarks on the Judgment of the ICJ on the Jurisdictional Immunity of a State," chapter 7 in this volume; and Christian Tomuschat, "The Case of Germany v Italy before the ICJ," chapter 6 in this volume.

${ }^{6}$ See e.g. Adam C. Belsky, Mark Merva and Naomi Roht-Arriaza, "Implied Waiver under the FSIA: A Proposed Exception to Immunity for Violations of Peremptory Norms of International Law," California Law Review 77 (1989), 365-415; see also US Court of Appeals, Hugo Princz v. Federal Republic of Germany, Decision of 1 July 1994, 26 F.3d 1166 (DC Cir. 1994), dissenting opinion of Judge Wald, para. 68; but see Georg Karl, Völkerrechtliche Immunität im Bereich der Strafverfolgung schwerster Menschenrechtsverletzungen (BadenBaden: Nomos, 2003), 133-34.
} 
Uerpmann-Wittzack, "Serious Human Rights Violations as Potential Exceptions to Immunity: Conceptual Challenges" (2013)

forfeiture, ${ }^{7}$ or they contend that a breach of ius cogens may not be qualified as an actus iure imperii for which immunity is granted under contemporary international law. ${ }^{8}$ In this volume, Thomas Giegerich illustrates how the latter approach was applied by a US court which relied on the commercial activity exception of the US Foreign Sovereign Immunities Act in order to discard immunity in a human rights case. ${ }^{9}$ It has also been tried to justify an exception to jurisdictional immunity by way of reprisal. ${ }^{10}$

Some of these constructions seem hardly convincing. Construing an implicit waiver by the state who violates fundamental norms, for instance, appears to be pure fiction. Other arguments have been put forward with much more emphasis. The most prominent example of a civilist approach to state immunity in case of serious violations of human rights is the argument based on a conflict of norms and on hierarchy. According to this approach, granting immunity would enter into conflict with the duty to protect human rights. Since fundamental human right norms form part of ius cogens, they must take precedence over state immunity which does not have such a higher rank. This argument has been invoked by six dissenting judges of the European Court of Human Rights (ECtHR) in the Al-Adsani case. ${ }^{11}$ The argument is a civilist one of construing and applying accepted rules of international law: If the obligation to grant immunity conflicts with a higher norm of international law, the latter will automatically prevail. Although there are fundamental values of the international community underlying the concept of ius cogens, the argument of giving ius cogens precedence in case of conflict with ordinary norms of international law is a formalist one.

\subsection{The Constitutional Approach: Sovereignty vs. Human Rights}

The constitutional approach goes beyond the formalist approach of applying given rules to a case. Rather, it relies on fundamental principles of the international order. If such principles

\footnotetext{
7 Juliane Kokott, "Mißbrauch und Verwirkung von Souveränitätsrechten bei gravierenden Völkerrechtsverstößen,” in Ulrich Beyerlin et al., eds., Recht zwischen Umbruch und Bewahrung (Berlin: Springer, 1995), 135-51, 148-49.

${ }^{8}$ But see ICJ, Jurisdictional Immunities (n. 4), para. 60, where the ICJ rebuts this argument.

${ }^{9}$ Thomas Giegerich, "The Holy See, a Former Somalian Prime Minister and a Confiscated Pissarro Painting: Recent US Case Law on Foreign Sovereign Immunity,” chapter 4 in this volume.

${ }^{10}$ For a cautious use of this argument see Giegerich, "Damages Claims" (n. 3), 232-35.

11 ECtHR, Case of Al-Adsani v. The United Kingdom, Grand Chamber Judgment of 21 November 2001, Application No. 35763/97, Joint Dissenting Opinion of Judges Rozakis and Caflisch joined by Judges Wildhaber, Costa, Cabral Barreto and Vajić.
} 
Uerpmann-Wittzack, "Serious Human Rights Violations as Potential Exceptions to Immunity: Conceptual Challenges" (2013)

enter into conflict in a given case, they must be weighed and balanced in order to develop a new rule of international law which realizes all principles as far as possible. ${ }^{12}$ So it becomes necessary to balance the principles underlying sovereign immunity on the one hand and human rights on the other hand, and to seek a solution which is proportional to the aim pursued.

Such an approach is familiar to human rights scholars and judges. So when the ECtHR is called upon to decide whether and to what extent the German yellow press may publish pictures showing Caroline von Hannover, then the court has to weigh and balance the right to respect for Caroline von Hannover's private life and freedom of the press, and it does so in a proportionality test. ${ }^{13}$ Isabelle Pingel in her contribution to the 2004 meeting of the French and the German Societies of International Law also applied this constitutional method. ${ }^{14}$ According to the ICJ, however, this approach cannot be transposed to questions of state immunity. As the court held in Jurisdictional Immunities, "[s]uch an approach would disregard the very nature of State immunity." 15

At the Basel Conference on Immunities in the Age of Global Constitutionalism which gave rise to this chapter, Theodor Schilling observed that the Al-Adsani judgment was not based on a constitutional reasoning. This is true. The majority of nine judges supporting the judgment essentially relied on state practice. ${ }^{16}$ According to the Court, immunities which have been "accepted by the community of nations" cannot in principle be regarded as a disproportionate

\footnotetext{
12 This theory has been explained by Robert Alexy, A Theory of Constitutional Rights, trans. Julian Rivers (Oxford: OUP, 2002), 47 ff; with regard to domestic constitutional law; see also Martin Borowski, "The Structure of Formal Principles - Robert Alexy's 'Law of Combination',' in Martin Borowski, ed., On the Nature of Legal Principles (Stuttgart: Franz Steiner Verlag, 2010), 19-36, 20-22; Robert Uerpmann, "La primauté des droits de l'homme: licéité ou illicéité de l'intervention humanitaire," in Christian Tomuschat, ed., Kosovo and the International Community: A Legal Assessment (The Hague: Kluwer, 2002), 65-86, 66 and 71-72.

${ }^{13}$ ECtHR (Third Section), Case of von Hannover v. Germany, Judgment of 24 June 2004, Application No. 59320/00, paras. 57 ff.; see also ECtHR, Case of von Hannover v. Germany (No. 2), Grand Chamber Judgment of 7 February 2012, Applications Nos. 40660/08 and 60641/08, paras. 99 and 108 ff.

14 Pingel, "L’immunité des États" (n. 3), 243, 245 and 247; see also Paul Ch. Bornkamm, "State Immunity against Claims Arising from War Crimes: The Judgment of the International Court of Justice in Jurisdictional Immunities of the State," German Law Journal 13 (2012): 773-82, 781.

${ }^{15}$ ICJ, Jurisdictional Immunities (n. 4), para. 106.

${ }^{16}$ ECtHR, Case of Al-Adsani (n. 11), para. 61 and passim.
} 
Uerpmann-Wittzack, "Serious Human Rights Violations as Potential Exceptions to Immunity: Conceptual Challenges" (2013)

restriction on the right of access to a court. ${ }^{17}$ So the proportionality test was discarded. Even the main dissenting opinion supported by six judges did not opt for a constitutional approach. Rather, these judges adopted a civilist reasoning based on conflict of norms and hierarchy. ${ }^{18}$ In fact, Judge Loucaides was the only to underline the importance of balancing competing interests in his dissenting opinion. ${ }^{19}$ The point is that judges of the ECtHR are acquainted with a constitutional method and that they are used to a human rights perspective. This might explain the narrow majority of nine to eight judges in Al-Adsani whereas the Jurisdictional Immunities judgment of the ICJ was supported by a much larger majority of twelve to three. ${ }^{20}$

\subsection{The State-Centred Approach: State Practice and Opinio Iuris}

In Jurisdictional Immunities the ICJ firmly sticks to a state-centred approach. According to this approach, the extent and the limits of state immunity must be established under international customary law which is made by States. In order to do so, the court analyses state practice and opinio iuris. ${ }^{21}$ The court also takes care to rebut some civilist arguments such as that of a conflict of norms. ${ }^{22}$ In essence, however, it relies on state practice throughout the judgment.

\section{Ethics in International Law}

\subsection{Ethics of Principled Conviction vs. Ethics of Responsibility}

Before the influence of ethics on international law can be addressed, it appears to be useful to distinguish two different kinds of ethics. Max Weber proposed such a distinction in his short treatise on "The Profession and Vocation of Politics" (Politik als Beruf) which first appeared

\footnotetext{
${ }^{17}$ Ibid., para. 56.

${ }^{18}$ See above n. 11.

${ }^{19}$ This was approved by Pingel, "L'immunité des États" (n. 3), 245.

${ }^{20}$ For the majority see ICJ, Jurisdictional Immunities (n. 4), para. 139.

${ }^{21}$ Ibid. (n. 4), paras. 54-55.

${ }^{22}$ Ibid. (n. 4), paras. 92-93.
} 
Uerpmann-Wittzack, "Serious Human Rights Violations as Potential Exceptions to Immunity: Conceptual Challenges" (2013)

in 1919. ${ }^{23}$ According to Weber, "ethics of principled conviction" (Gesinnungsethik) must be distinguished from "ethics of responsibility" (Veranwortungsethik). ${ }^{24}$

Those who follow an ethics of conviction only consider the value of the deed as such. Under such ethics, it seems quite clear that courts must give justice to the victims of serious human rights violations regardless of state immunity: "fiat iustitia et" - as a critic may add - "pereat mundus".

By contrast, those who follow ethics of responsibility will consider the consequences: "quidquid agis, prudenter agas et respice finem". Judge Pellonpää applied this in his concurring opinion to the Al-Adsani judgment. ${ }^{25}$ He highlighted the need for international cooperation which required a legal framework, and he pointed to the fact that state immunity formed part of this framework. Ambassador Ney argued similarly at the Basel conference which led to the present volume. ${ }^{26}$ Judge Pellonpää even went so far as to state that granting Mr. Al-Adsani access to court regardless of state immunity might have become a "Phyrric victory" for human rights. ${ }^{27}$ At the Basel conference, Christian Tomuschat argued similarly with regard to the Jurisdictional Immunities Case: accepting the Italian claim would have

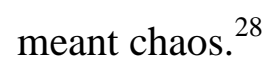

\subsection{The Pretended Value-Neutrality of Legal Construction}

The civilist, constitutional and state-centred approaches analysed in section 2 each take a different attitude towards ethics. The civilist approach seems to be value-free. When scholars analyse the question of immunities in terms of conflict of norms and hierarchy, they choose a formalist reasoning. It is true that the very concept of ius cogens implies the idea of fundamental values of the international community which, in a constitutional order, take the

\footnotetext{
${ }^{23}$ Max Weber, Politik als Beruf (München: Duncker und Humblot, 1919); English translation: Max Weber, "The Profession and Vocation of Politics," in Max Weber, Political Writings, trans. Ronald Speirs (Cambridge: CUP, 1994), 309-69.

${ }^{24}$ Weber, "Profession and Vocation" (n. 23), 359 et seq.; Weber, Politik als Beruf (n. 23), 56 et seq.

${ }^{25}$ ECtHR, Case of Al-Adsani (n. 11), concurring opinion of Judge Pellonpää joined by Judge Bratza.

${ }^{26}$ Martin Ney, “Sovereign Immunities of States: A German Perspective,” chapter 2 in this volume.

27 In a more sober way, Matthias Kloth and Manuel Brunner, "Staatenimmunität im Zivilprozess bei gravierenden Menschenrechtsvereltzungen," Archiv des Völkerrechts 50 (2012): 218-44, 238, allude to the political consequences of such a decision.

${ }^{28}$ Christian Tomuschat, “The Case of Germany v Italy before the ICJ," chapter 6 in this volume.
} 
Uerpmann-Wittzack, "Serious Human Rights Violations as Potential Exceptions to Immunity: Conceptual Challenges" (2013)

form of principles. ${ }^{29}$ However, the inherent value judgments are not made explicit when a possible exception to immunities in cases of serious violations of human rights is technically analysed in terms of conflict of norms and hierarchy.

\subsection{Making Values Explicit: The Constitutional Approach}

The constitutional approach makes value judgments explicit. It requires an operation of weighing different principles and of balancing them. When it comes to immunities, it is quite easy to evaluate the interest of realising human rights which is opposed to granting immunities. It is more difficult to analyse the principles underlying sovereign immunity. Here it becomes crucial to analyse the importance of sovereign immunity for international relations as Judge Pellonpää did in Al-Adsani. ${ }^{30}$ In a reply to this presentation, Anne Peters argued that state immunity was "purely instrumental", the state having "no instrinsic value". This is true at least from a German point of view, where the concept of a State having a dignity of its own has been discredited in the first half of the twentieth century. ${ }^{31}$ Rather, the underlying values of state immunity are crucial. To the extent that immunities serve the functioning of international relations they may promote peace and by that even save human lives.

\subsection{The Realism of a State-Centred Approach}

When international judges and scholars rely on state practice and opinio iuris as the ICJ did in Jurisdictional Immunities and as the ECtHR majority had done before in Al-Adsani, they are discharged from making own value judgments. Therefore, their approach may be called a realistic one. ${ }^{32}$ This does not mean that ethics lose their importance for international law. However, it is not up to international judges to introduce value judgments in their decisions. Rather, ethics remain important to the extent that state practice is motivated by ethical considerations and that states rely on ethics in their reasoning which leads to the establishment of opinio iuris.

\footnotetext{
${ }^{29}$ For an analysis of the relationship between principles and values see Alexy, Theory (n. 12), 86 et seq.

${ }^{30}$ See above n. 25.

${ }^{31}$ In the discussion, President Guillaume explained that the French State, which had preceded the French nation, is still conceived as a value. Pierre-Marie Dupuy agreed.

${ }^{32}$ See also Bornkamm, "State Immunity” (n. 14), 778.
} 
Uerpmann-Wittzack, "Serious Human Rights Violations as Potential Exceptions to Immunity: Conceptual Challenges" (2013)

\section{Conclusion}

Legal arguments with regard to immunities in cases of serious human rights violations may be classified into three different approaches: a civilist, a constitutional and a state-centred one. The state-centred approach is that of traditional international law. It is followed by the ICJ and it draws its legitimacy from state consent. The civilist approach is equally recognized in international law. The ICJ accepted the idea that a norm of ius cogens would take precedence over another norm of international law in case of conflict, whereas it took care to explain that there was no such conflict of norms. ${ }^{33}$ However, a civilist method becomes problematic where it is used in order to implement certain value judgments without making them explicit.

The constitutional approach is a matter of fact in constitutional systems like that of the ECHR. Weighing and balancing competing principles is an essential element of ECtHR case law. However, it seems that this method requires a constitutional court which can authoritatively decide on the right balance to be struck in a given case. ${ }^{34}$ While the ECtHR is such a constitutional court with compulsory jurisdiction, general international law does not show the same degree of constitutionalization, and the jurisdiction of the ICJ still depends on state consent according to article 36 of the Statute of the ICJ. Therefore, autonomous constitutional reasoning is highly problematic within the context of general international law.

This does not mean that there is no space for constitutional reasoning in general international law. First of all, a reasoning based on principles may be used in order to test legal constructions and in order to make inherent value judgments explicit. Moreover, states do not behave in an ethical vacuum. A reasoning based on legal principles may guide state action and it may help to explain why states behave in a certain way. Applied to the question of immunities and their limits this means that due regard should be paid to the requirements of international co-operation within a world without central authority. ${ }^{35}$ This may be hard to accept under the ethics of conviction, but it corresponds to the ethics of responsibility as understood by Max Weber.

\footnotetext{
${ }^{33}$ See above n. 22.

${ }^{34}$ See Uerpmann, "Primauté des droits de l'homme" (n. 12), 79-85; Christian Tomuschat, "The International Law of State Immunity and its Development by National Institutions," Vanderbilt Journal of Transnational Law 44 (2011): 1105-40, 1140, calls for the "guiding hand of an international organization (...)".

${ }^{35}$ See also Kloth and Brunner, “Staatenimmunität im Zivilprozess” (n. 27), 242.
} 